\title{
ARTIFICIAL INTELLIGENCE AND MULTIPLE MODELS APPLIED TO PHYTOSANITARY AND NUTRITIONAL ASPECTS THAT INTERFER IN THE PHYSIOLOGICAL POTENTIAL OF SOYBEAN SEEDS
}

\author{
Murilo Vieira Loro ${ }^{1}$, Ivan Ricardo Carvalho ${ }^{1}$, José Antonio Gonzalez da Silva ${ }^{1}$, Natã Balssan \\ Moura $^{1}$, Danieli Jacoboski Hutra ${ }^{1}$, Francine Lautenchleger ${ }^{2}$ \\ ${ }^{1}$ Northwestern Regional University of the State of Rio Grande do Sul, Ijuí - Rio Grande do Sul State, Brazil \\ E-mails: loro@gmail.com, carvalho.irc@gmail.com, silva@gmail.com, moura@gmail.com, hutra@gmail.com \\ ${ }^{2}$ Midwestern State University (Unicentro), Guarapuava - Paraná State, Brazil \\ E-mail: lauter@gmail.com
}

\section{ABSTRACT}

The objective of this work was to evaluate the interference of physical, nutritional, sanitary, and genetic aspects in the quality of soybean seeds. The experimental design used was randomized blocks, using 55 soybean F6 genotypes, with 4 replications. In this study, thousand seeds mass, germinated seeds, accelerated aging, tetrazolium, phytosanitary indicators (Aspergillus flavus, Cercospora kikuchii, Fusarium graminearum, Fusarium semisectum, and Bacteriosis), seed nutritional indicators (nitrogen, phosphorus, potassium, calcium, magnesium, sulfur, boron, copper, iron, manganese, zinc, sodium, and molybdenum). The physiological quality of the seeds is negatively affected by the health aspects of Cercospora kikuchii, Aspergillus flavus, Fusarium semisectum and Bacteriosis. In addition, nutritional aspects also act negatively due to the presence of salts, and positively due to the levels of P. Likewise, $\mathrm{Zn}$, Mo and $\mathrm{K}$ are correlated as strong indicators of seed vigor levels. The developed genotypes have excellent behavior towards pathogens and seed nutrition, contributing to high quality seed production.

Keywords: Glycine max, interrelationships, multivariate selection methods

\section{INTELIGÊNCIA ARTIFICIAL E MODELOS MÚLTIPLOS APLICADOS A ASPECTOS FITOSSANITÁRIOS E NUTRICIONAIS QUE INTERFEREM NO POTENCIAL FISIOLÓGICO DE SEMENTES DE SOJA}

\section{RESUMO}

O objetivo deste trabalho foi avaliar a interferência de aspectos físicos, nutricionais, sanitários e genéticos na qualidade de sementes de soja. O delineamento experimental utilizado foi blocos ao acaso, com 55 genótipos F6 da soja, e 4 repetições. As variáveis analisadas foram: massa 


\section{ARTIFICIAL INTELLIGENCE AND MULTIPLE MODELS APPLIED TO PHYTOSANITARY AND \\ NUTRITIONAL ASPECTS THAT INTERFER IN THE PHYSIOLOGICAL POTENTIAL OF SOYBEAN SEEDS}

de mil sementes, sementes germinadas, envelhecimento acelerado, tetrazólio, indicadores fitossanitários (Aspergillus flavus, Cercospora kikuchii, Fusarium graminearum, Fusarium semisectum e Bacteriose), nutricionais (nitrogênio, fósforo, potássio, cálcio, magnésio, enxofre, boro, cobre, ferro, manganês, zinco, sódio e molibdênio). A qualidade fisiológica das sementes é afetada negativamente pelos aspectos sanitários de Cercospora kikuchii, Aspergillus flavus, Fusarium semisectum e Bacteriose, além disso, os aspectos nutricionais atuam negativamente devido a presença de sais, e positiva pelos teores de P. Assim, Zn, Mo e K são correlacionados como fortes indicadores dos níveis de vigor das sementes. Os genótipos desenvolvidos apresentam excelente comportamento frente a patógenos e nutrição das sementes, contribuindo para a produção de sementes de alta qualidade.

Palavras-chave: Glycine max, inter-relacionamentos, métodos de seleção multivariada

\section{INTRODUCTION}

Soybean (Glycine max) is a legume of great importance worldwide due to its high productive potential and nutritional value, in addition to its use in agro-industries (GABARD et al., 2020; SZARESKI et al., 2018a). To achieve high productivity and meet this demand from the consumer market, some management practices are essential. Among these, the choice of seeds of high physiological quality are responsible for generating uniform plants with high productive capacity (SZARESKI et al., 2018b).

The uniform establishment of the plant stand is directly related to the quality of this seed at the time of sowing, aiming to guarantee an adequate initial population of plants, which even when exposed to adverse environmental conditions, has the ability to express high yields (STRUKER et al., 2019). According to studies carried out by Cantarelli et al. (2015), the low physiological quality of the seeds is linked to the reduction of the population and the unevenness of plants in the field, which causes greater intraspecific competition.

Different factors are capable of influencing the physiological quality of these seeds, among them, the nutritional status of the plants in the reproductive period, which in deficiency conditions, lead to the reduction of the nutritional quality of the seed (SALUM et al., 2008). Therefore, nutrition management is essential for the proper development of organs, especially the formation of the endosperm, responsible for storing seed reserves. 
In addition, biotic factors such as phytopathogenic microorganisms present in seeds compromise their quality in the field and in the post-harvest and storage stages (MEDEIROS et al., 2014). Another factor capable of influencing the quality of the seeds is the physical damage as they reduce the vitality of the seed, favoring the development of phytopathogens, these damages occur from the moment of harvest until the beginning of sowing. According to Albaneze et al. (2018), the harvest carried out with low moisture content causes broken seeds and mechanical damage. Allied to this, the aspect of pure seed and free of inert materials such as clods, broken, malformed seeds and insects, which directly impact on physical quality.

Seed quality can also be influenced by genetic aspects, likewise, genetic aspects influence seed quality. Valário et al. (2014) comment that it is becoming increasingly difficult to assess genetic purity, due to numerous cultivars and the genetic similarity between them, requiring laboratory techniques to improve the distinction. Genetic purity can be modified, mainly in production fields, by some processes such as mutations and undesirable pollinations. Therefore, efficiency is sought in the production fields, strictly following the quality control, to achieve homogeneity within the lots. In this context, understanding the implications for seed quality can enable actions for the production of high quality seeds, ensuring that the crop expresses its productive potential. Thus, the objective of this work was to evaluate the interference of physical, nutritional, sanitary and genetic aspects in the quality of seeds.

\section{MATERIAL AND METHODS}

The study was carried out with seeds from the IRC Soybean Breeding Program, located in the city of Campos Borges, state of Rio Grande do Sul, Brazil, at coordinates $28^{\circ} 53$ ' $10^{\prime}$ 'S and $52^{\circ}$ 59' 55 " W and altitude of 513 meters, in the 2018/19 crop season. The soil is characterized as a red dystrophic Latosol (Oxisol) and the climate, according to Köppen, is subtropical Cfa. The experimental design used was randomized blocks, using 55 soybean F6 genotypes, with 4 replications. The experimental plots were composed of four rows of $5 \mathrm{~m}$ in length, spaced $0.5 \mathrm{~m}$ apart, using two central rows as the useful area, eliminating their ends as a border, with the evaluation of 15 plants in the useful area of each experimental unit.

Sowing was carried out in the first half of November 2018, and the management required by the crop was carried out uniformly in all experimental plots, with fertilization of $250 \mathrm{~kg} / \mathrm{ha}^{-1}$ of the formula $05-20-20$, distributed and incorporated into the sowing furrow. The sowing density 


\section{ARTIFICIAL INTELLIGENCE AND MULTIPLE MODELS APPLIED TO PHYTOSANITARY AND \\ NUTRITIONAL ASPECTS THAT INTERFER IN THE PHYSIOLOGICAL POTENTIAL OF SOYBEAN SEEDS}

was 260 thousand plants per hectare for all genotypes. The management of weeds, insect pests and diseases were carried out according to the needs of the crop, seeking to minimize the external effects on the result of the experiment. Pre-sowing desiccation was carried out, and fungicide applications occurred in stages V5, R1 and R5.

The harvest was carried out manually and the evaluations of the physiological indicators such as thousand seeds mass (TGM, grams) (obtained through the average weighing of eight samples of one hundred seeds), germinated seeds (G, percentage), accelerated aging (AA, percentage), tetrazolium (TZ, percentage), phytosanitary indicators: Aspergillus flavus (AS, percentage), Cercospora kikuchii (CK, percentage), Fusarium graminearum (FG, percentage), Fusarium semisectum (FS, percentage), and Bacteriosis (BC, percentage), and seed nutritional indicators such as nitrogen $\left(\mathrm{N}, \mathrm{g} \mathrm{kg}^{-1}\right)$, phosphorus $\left(\mathrm{P}, \mathrm{g} \mathrm{kg}^{-1}\right)$, potassium $\left(\mathrm{K}, \mathrm{g} \mathrm{kg}^{-1}\right)$, calcium $(\mathrm{Ca}$, $\left.\mathrm{g} \mathrm{kg}^{-1}\right)$, magnesium $\left(\mathrm{Mg}, \mathrm{g} \mathrm{kg}^{-1}\right)$, sulfur $\left(\mathrm{S}, \mathrm{g} \mathrm{kg}^{-1}\right)$, boron $\left(\mathrm{B}, \mathrm{mg} \mathrm{kg}^{-1}\right)$, copper $\left(\mathrm{Cu}, \mathrm{mg} \mathrm{kg}^{-1}\right)$, iron (Fe, mg kg-1), manganese ( $\left.\mathrm{Mn}, \mathrm{mg} \mathrm{kg}{ }^{-1}\right)$, zinc $\left(\mathrm{Zn}, \mathrm{mg} \mathrm{kg}^{-1}\right)$, sodium $\left(\mathrm{Na}, \mathrm{mg} \mathrm{kg}^{-1}\right)$, and molybdenum (Mo, $\mathrm{mg} \mathrm{kg}^{-1}$ ).

The data obtained were subjected to normality and homogeneity analysis of residual variances. Subsequently, analysis of variance was performed at 5\% probability, with the aim of verifying the interaction between soybean genotypes $\mathrm{x}$ health aspects $\mathrm{x}$ nutritional aspects $\mathrm{x}$ physical aspects in physiological attributes of the seed. Canonical analyzes were carried out in order to clarify the relationship between each of the sets of variables, finding a small number of linear combinations, in order to maximize the possible correlations between the groups. Significant interactions have been revealed for the simple effect. The Mahalanobis algorithm and the UPGMA grouping method were used to develop the dendrogram and an analysis of the main components of the Biplot was applied to present the multiple trends of the effects on the treatments and characters. Subsequently, linear correlation was performed.

\section{RESULTS AND DISCUSSION}

The graphs (Figure 1) show the nutritional averages in relation to the concentrations in the seeds. The results obtained for the nutrients (Figure 1a) were as follows: calcium (Ca) of $2.7 \mathrm{mg}$ $\mathrm{kg}^{-1}$, being similar to the value exposed by Brunini et al. (2016) in 11 soybean cultivars, where it




nutrients are 2.3 and $2.1 \mathrm{mg} \mathrm{kg}^{-1}$ similar to those shown also by Brunini et al. (2016) in soybean

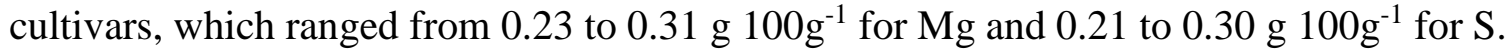
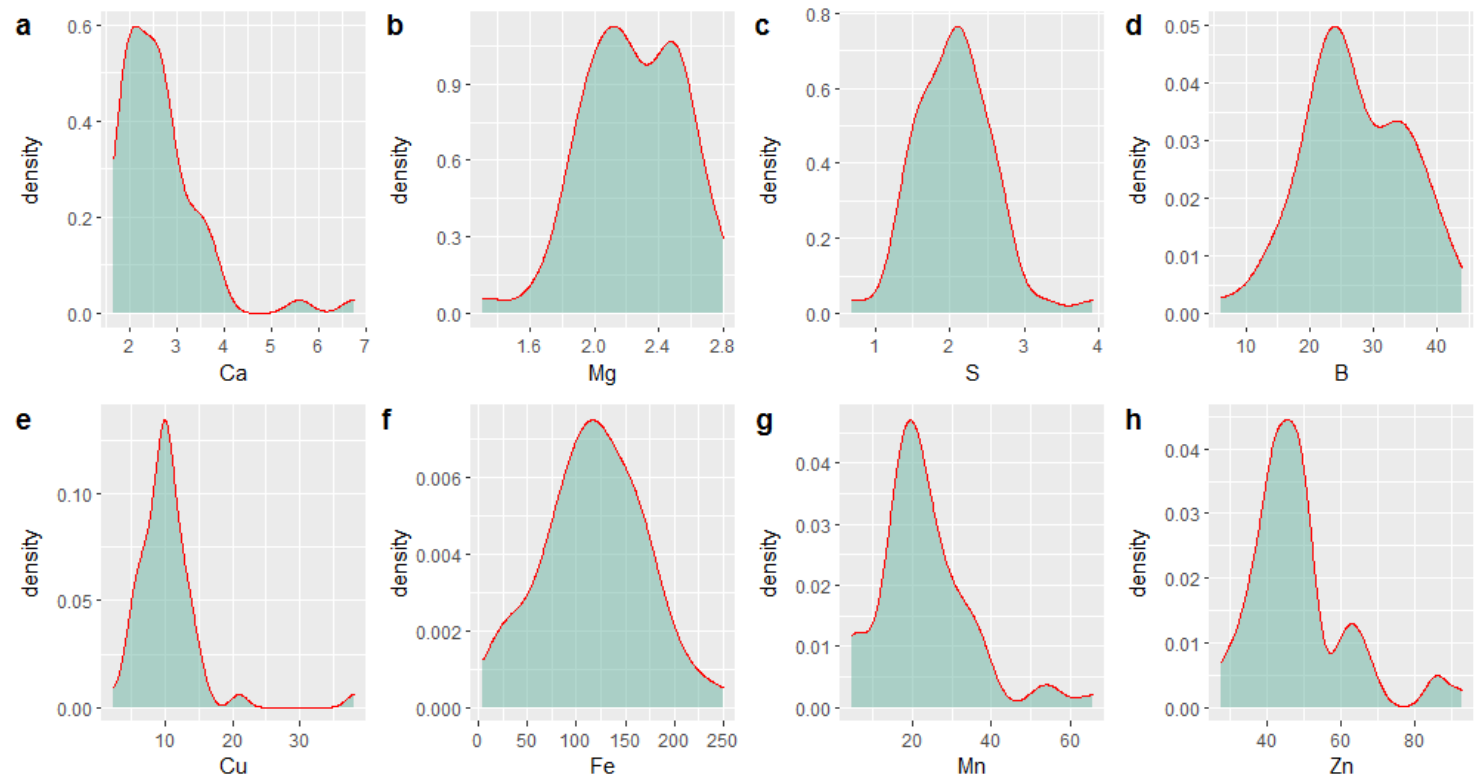
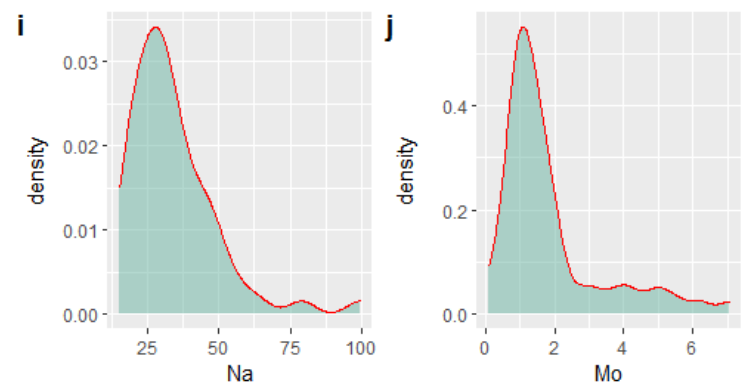

Figure 1. Graphs of average effects and frequencies of the variables. Calcium $(\mathrm{Ca})$, Magnesium $(\mathrm{Mg})$, Sulfur (S), Boron (B), Copper (Cu), Iron (Fe), Manganese (Mn), Zinc (Zn), Sodium (Na) and Molybdenum (Mo), Campos Borges - Rio Grande do Sul State, 2019.

Comparing the levels of copper $(\mathrm{Cu})$, iron $(\mathrm{Fe})$, manganese $(\mathrm{Mn})$, and zinc $(\mathrm{Zn})$ of 10.3, 108.7, 24.0 and 47.2 $\mathrm{mg} \mathrm{kg-1} \mathrm{respectively,} \mathrm{with} \mathrm{those} \mathrm{obtained} \mathrm{by} \mathrm{Brunini} \mathrm{et} \mathrm{al.} \mathrm{(2016),} \mathrm{which}$ were from 1 to $1.36 \mathrm{mg} 100 \mathrm{~g}-1$ for $\mathrm{Cu}, 10.43$ to $16.23 \mathrm{mg} 100 \mathrm{~g}-1$ for Fe, 2.10 to $2.56 \mathrm{mg} 100 \mathrm{~g}-1$ for $\mathrm{Mn}$ and 3, 23 to $3.83 \mathrm{mg} 100 \mathrm{~g}-1$ for $\mathrm{Zn}$, it is noticed that the values are higher. The micronutrients such as boron (B) have an average value of $27.6 \mathrm{mg} \mathrm{kg}-1$, sodium (Na) of $33.0 \mathrm{mg}$ $\mathrm{kg}-1$ and molybdenum (Mo) of $1.8 \mathrm{mg} \mathrm{kg-1}$. The thousand grain mass (TGM) obtained was 164.2 g-1, with a variation of 120 to 210 g-1, showing satisfactory results. For seed quality tests (Figure 
$2 \mathrm{~b}$ ), the variables germination (G), accelerated aging (AA) and tetrazolium (TZ), present average values of $89.8 \%, 82.9 \%$ and $86.5 \%$ respectively.

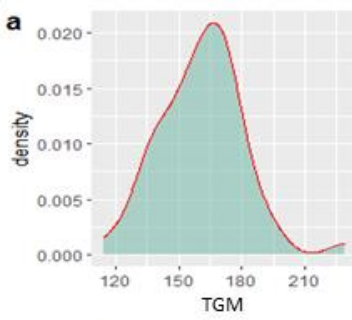

e

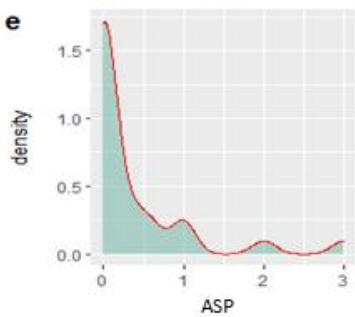

i

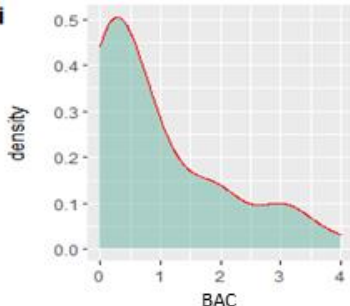

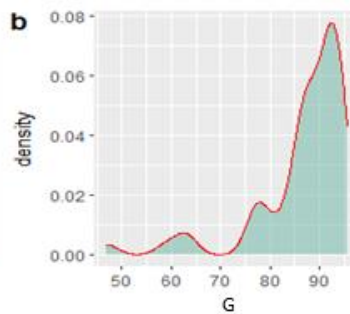
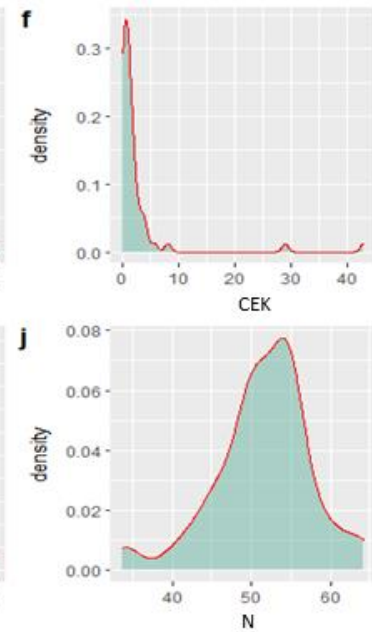

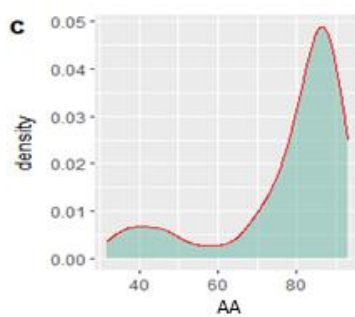

g
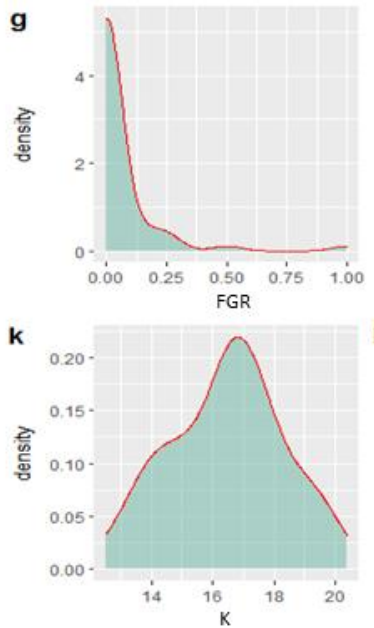

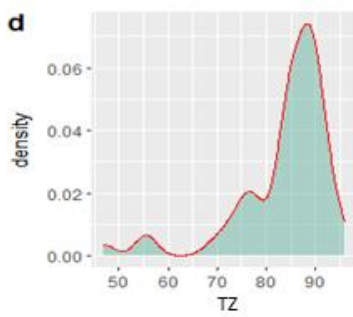

h
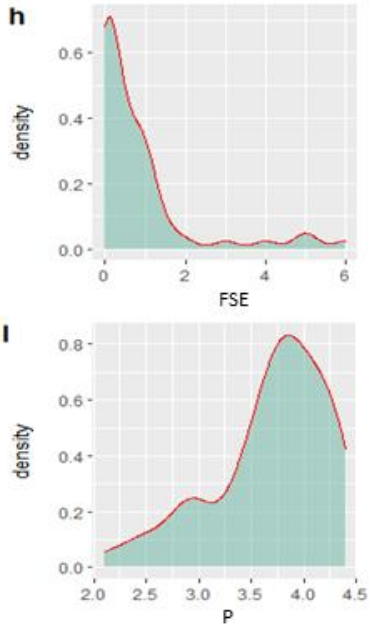

Figure 2. Graphs of average effects and frequencies of the variables of analysis of physiological, health and nutritional quality. Thousand Grain Mass (TGM), Germination (G), Accelerated Aging (AA), Tetrazolium (TZ), Aspergillus flavus (ASP), Cercospora kikuchii (CEK), Fusarium graminearum (FGR), Fusarium semisectum (FSE), Bacteriosis (BAC), Nitrogen (N), Potassium (K), Phosphorus (P), Campos Borges - Rio Grande do Sul State, 2019.

Regarding the levels of pathogens, Cercospora kikuchii (CEK) was the most evident among the $1.6 \%$ diseases, however, it had an extremely lower occurrence when compared with the results of Pereira et al. (2017) who used soybean seed samples with $8.68 \%, 70.10 \%$ and $85.30 \%$ incidence of the pathogen. It is noteworthy the superior tolerance of new genotypes under development. For the other pathogens, the incidence levels did not exceed $2 \%$, considered low.

The macronutrients nitrogen $(\mathrm{N})$ and potassium $(\mathrm{K})$ exhibit the highest concentrations in the seed composition. Thus, the value obtained for $\mathrm{N}$ was $51.9 \mathrm{~g} \mathrm{~kg}^{-1}$, consistent with the result of

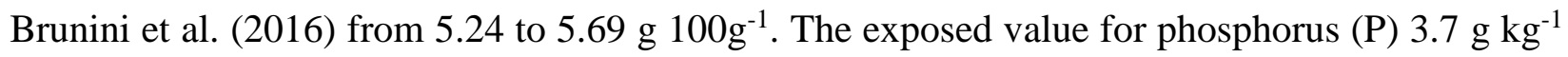


is lower than found by Brunini et al. (2016), as it had a range of 5.3 to $5.7 \mathrm{~g} \mathrm{~kg}^{-1}$. Although, the levels of $\mathrm{P}$ are lower when compared to the other macronutrients.

The analyzes referring to Pearson linear correlation are presented (Figure 3). Through those analyses it is possible to identify the correlations between the variables tested, so that the values of the correlation vary from -1 (strong and negative correlation) to 1 (strong correlation) and 0 when there is no correlation. It is noticed that the thousand grain mass is negatively correlated with $\mathrm{Zn}$ and $\mathrm{Mn}$, that is, as the thousand grain mass increases, the content of these nutrients decreases, which differs from that found by Oliveira et al. (2018) which shows the positive relationship of $\mathrm{Zn}$ with the thousand grain mass and different from Carvalho et al. (2016) who describes insignificance in the thousand grain mass in the presence of Mn. Likewise, the increase in the thousand grain mass is linked to the reduction in the incidence of Fusarium semisectum. However, $\mathrm{Cu}$ has a positive correlation, while increasing the thousand grain mass, there is an increase in $\mathrm{Cu}$.

It is also noticed that $\mathrm{Mo}, \mathrm{Na}, \mathrm{Zn}$, and Fe reduce germination, because both are salts. According to Gordin et al. (2012), the presence of salts causes injuries, promote ionic imbalance and toxicity, in addition, with the presence of them, the reduction of water potential occurs, inhibiting the growth of roots and shoot. However, $\mathrm{P}$ showed a positive correlation, the increase in nutrient is linked to improved seed germination, which differs from that found by Marin et al. (2015), which conclude that phosphorus does not increase germination levels.

Pathogens such as Bacteriosis, Fusarium semisectum and Cercospora kikuchii, when present, indicate an unfavorable effect on seed germination, corresponding to the result found by Pereira et al. (2017). The incidence of Cercospora kikuchii increases the incidence of abnormal seedlings in germination who state that there is a $12.8 \%$ reduction in germination, when compared to seeds with and without the incidence of the pathogen. The same was highlighted by Pereira et al. (2017), where seeds contaminated with Cercospora kikuchii, when treated with fungicides, had a lower incidence of abnormal seedlings, due to the effective control of the pathogen. In the analysis of accelerated aging, the nutrients $\mathrm{Mo}, \mathrm{Na}$ and $\mathrm{Zn}$ follow the same negative correlation as in germination, as well as the pathogens Aspergillus flavus, Bacteriosis, Fusarium semisectum and Cercospora kikuchii. The same is perceived for tetrazolium, however, the diseases that affect this test are Fusarium semisectum and Bacteriosis, the latter possibly because it is related to physical damage to the seeds, that is, they penetrate the organ through openings caused by biotic or abiotic processes. 


\section{ARTIFICIAL INTELLIGENCE AND MULTIPLE MODELS APPLIED TO PHYTOSANITARY AND NUTRITIONAL ASPECTS THAT INTERFER IN THE PHYSIOLOGICAL POTENTIAL OF SOYBEAN SEEDS}

\begin{tabular}{|c|c|c|c|c|c|c|c|c|c|c|c|c|c|c|c|c|c|c|c|c|c|c|}
\hline M & G & AA & TZ & ASP & CEK & FGR & FSE & $B A C$ & $\mathrm{~N}$ & K & P & $\mathrm{Ca}$ & $\mathrm{Mg}$ & $\mathrm{s}$ & B & $\mathrm{Cu}$ & $\mathrm{Fe}$ & $\mathrm{Mn}$ & $\mathrm{Zn}$ & $\mathrm{Na}$ & Mo & \\
\hline & 0.14 & $0.13^{\circ}$ & 0.1 & - 0000000 & $-0.14^{\circ}$ & 0.1 & -0.3 & $-0.13^{\circ}$ & -0.091 & - 0403 & 0.035 & 0016 & $0.14^{\circ}$ & $0.13^{\circ}$ & -0.14 & $0.22^{\prime \prime}$ & 0.098 & $-0.17^{\circ}$ & $-0.18^{\circ}$ & 0062 & -0.13 & 몰 \\
\hline & & 0.83 & 0.83 & -0.11 & -0.26 & -0.036 & -0.42 & -0.46 & 0000 & 000 & $0.18^{\circ}$ & $-\infty 002$ & -0.097 & 0.014 & $0.14^{\circ}$ & 007 & $-0.10^{\circ}$ & 0.059 & -0.29 & $-0.17^{\circ}$ & -0.24 & $\circ$ \\
\hline & & & 0.75 & $-0.17^{\circ}$ & $0.2^{\prime \prime}$ & $\infty 01$ & -0.39 & -0.38 & 0012 & oots & ooss & -0065 & -0.012 & 0.014 & 0.11 & ooess & -0.089 & 0003 & -0.31 & $-0.18^{\circ}$ & $-0.17^{\circ}$ & $\xi$ \\
\hline & & & & -016 & $-0.13^{\circ}$ & -0067 & -0.33 & -0.43 & -000017 & 00054 & 0.11 & -0050 & -0065 & 0.054 & 0.099 & 0.12 & - 000 & ooes & $-0.23^{-1}$ & -0.23 & 0.28 & $\vec{A}$ \\
\hline & & & & & -00046 & -ocoss & 0.062 & 00016 & 00008 & -0005 & -0.05s & 000 & -0.036 & .0077 & -20065 & $-0.14^{\circ}$ & -0007 & -0.062 & 0028 & - -013 & $0.10^{\circ}$ & हू \\
\hline & & & & & & oors & 0.28 & $-0.13^{\circ}$ & $0.17^{\circ}$ & $-0.15^{\circ}$ & -0005 & -2054 & -0.11 & $0.2^{\prime \prime}$ & 0.097 & -0028 & $0.2 e^{-m}$ & -0.014 & $0.13^{\circ}$ & $0.13^{\circ}$ & 0.11 & 骨 \\
\hline & & & & & & & 0.10 & 0.094 & $-0.14^{\circ}$ & $0.10^{\circ}$ & 0016 & -0.11 & -0.14 & 0.1 & -0.1 & 0074 & -0059 & -00095 & 0.087 & -0036 & -0078 & 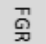 \\
\hline & & & & $\vdots$ & & & & $0.21^{\prime \prime}$ & $-\cos 5$ & 0010 & -0.066 & -0.12 & -0.11 & 0.1 & -0003 & $-\infty 044$ & oors & 0.085 & 0.39 & $\cos 4$ & $0.18^{\circ}$ & 怘 \\
\hline & & & & : & & & & & -0.1 & oor & -0045 & 0.061 & 0.1 & -0.024 & $-0.2^{\prime \prime}$ & 0.11 & $0.15^{\circ}$ & -0.064 & $0.21^{\prime \prime}$ & 0018 & 0.11 & 塄 \\
\hline & & & & & & & & & & & $0.33^{3}$ & -0.093 & $\infty 00$ & -8007 & 0.1 & $-\infty 0000$ & $-0.15^{\circ}$ & So11 & 00006 & $-\infty a c$ & $-\infty 00 a$ & $z$ \\
\hline & & & & & & & & & & & 0. & $0.18^{\circ}$ & $0.3^{*}$ & -0.1 & -0024 & -20014 & -0000 & 0.1 & 00002 & 0.097 & $-0.14^{\circ}$ & $\pi$ \\
\hline & & & & & & & & & & & & 087 & 0.088 & 0.038 & $0.21^{\prime \prime}$ & $-\infty 086$ & -0.27 & 0.25 & -0.09 & 00056 & -0.097 & 0 \\
\hline & & & & & & & & & & & & & 0.47 & -0.11 & -002 & $0.15^{\circ}$ & $0.23^{\prime \prime}$ & $0.14^{\circ}$ & -0.083 & 0.42 & 0.09 & $\curvearrowright$ \\
\hline & & & & & & & & & & & & & & & -0.1 & $-\infty \infty$ & 0.36 & .0 .23 & $0.25^{-1}$ & 0.51 & soses & 줌 \\
\hline & & & & & & & & & & & & & & & & $0.24^{\prime \prime}$ & 0008 & oass & $0.14^{\circ}$ & -0.11 & ooes & $n$ \\
\hline & & & & & & & & & & & & & & & & -0012 & 0.24 & 0.33 & $-\infty 019$ & -00058 & $0.222^{\prime \prime}$ & ద \\
\hline & & & & & & & & & & & & & & & & & 0.091 & -0.11 & 0071 & $00 t$ & -0.12 & $\varepsilon$ \\
\hline & & & & & & & & & & & & & & & & & & -0.29 & $-\infty 00056$ & $0.3^{m-m}$ & 0.087 & त \\
\hline & & & & & & & & & & & & & & & & & & & 0.12 & -0.21 & $0.17^{\circ}$ & ’ \\
\hline & & & & & & & & & & & & & & & & & & & & -0.052 & 0.12 & $N$ \\
\hline & & & & & & & & & & & & & & & & & & & & & 0.095 & ฐ \\
\hline & & & & & & & & & & & & & & & & & & & & & & 5 \\
\hline
\end{tabular}

Figure 3. Estimates of Pearson's linear correlation for nutritional, health, nutritional and vigor and germination tests in 55 soybean genotypes, Campos Borges - Rio Grande do Sul State, 2019. Pearson linear correlation coefficients $(n=90)$ significant at $5.00 \%$ probability. Thousand Grain Mass (TGM), Germination percentage (G), Accelerated aging (AA); Tetrazolium (TZ), Aspergillus flavus (ASP), Cercospora kikuchii (CEK), Fusarium graminearum, (FGR), Fusarium semisectum (FSE), Bacteriosis (BAC), Nitrogen (N), Potassium (K), Phosphorus (P), Calcium (Ca), Magnesium (Mg), Sulfur (S), Boron (B), Copper $(\mathrm{Cu})$, Iron (Fe), Manganese (Mn), Zinc ( $\mathrm{Zn})$, Sodium (Na), Molybdenum (Mo).

It is also added that pathogens such as Aspergillus flavus have a higher incidence as there is an increase in the Mo content in the seed composition, differently from Cercospora kikuchii, which has a higher incidence linked to the presence of Fe, S and $\mathrm{N}$, moreover, its incidence contributes to the development of Fusarium semisectum. Therefore, the development of these pathogens is related to the optimal conditions for plant nutrition and the environment. Fusarium graminearium, on the other hand, is linked to the addition of $\mathrm{K}$ in the seed, thus, present in areas with high levels of $\mathrm{K}$ in the soil, different from the results found by Zambiazzi et al. (2017), the supply of K to plants reduces the incidence of pathogens, mainly of the genus Fusarium sp. Due to 
the increase of $\mathrm{Mo}$ and $\mathrm{Zn}$ in the seeds, there is an increase in the existence of fungi of Fusarium semisectum, the same occurs for Bacteriosis when there are high levels of $\mathrm{Zn}$ in the seeds, however, there is a decrease in the pathogen with the addition of B.

The nutrients also exhibit correlations, the increase in Nitrogen has an increase in $\mathrm{P}$ and $\mathrm{K}$, with a positive correlation between $\mathrm{K}$ and $\mathrm{Mg}, \mathrm{Ca}$ and $\mathrm{P}$. As well, the increase in $\mathrm{P}$ provides an increase in $\mathrm{Mn}$ and $\mathrm{B}$ levels, reducing levels of $\mathrm{Fe}$. $\mathrm{Ca}$, on the other hand, has a positive correlation with $\mathrm{Na}, \mathrm{Fe}$ and $\mathrm{Mg}$, the latter is contrasting with $\mathrm{Zn}, \mathrm{Mn}$ and $\mathrm{S}$, as the levels of $\mathrm{Mg}$ increase, the levels of these nutrients decrease, but the opposite occurs in relation to $\mathrm{Na}$ and $\mathrm{Fe}$.

Sulfur has a single correlation, which is described as positive, increasing the $\mathrm{Cu}$ level as the sulfur increases. The micronutrients are fundamental in the metabolic processes of plants, and have correlations between them, therefore, it is noticed that as the concentration of $\mathrm{Fe}$ in the seed increases, there is an increase in $\mathrm{Na}$ and a decrease in $\mathrm{Mn}$, in addition, Mn provides a higher Mo content and a reduction in $\mathrm{Na}$.

To obtain seeds of high physiological quality, nutrition has an important contribution, mainly $\mathrm{P}$, which promotes increased germination. For this, the management of this nutrient during the crop cycle must be adjusted according to soil analysis. In addition, the dynamics of this nutrient depends on environmental factors that control soil fauna, which immobilize the orthophosphate ions (SANTOS, GATIBONI \& KAMINSKI, 2008), making it available to plants. The reduction in physiological quality of the seeds occurs mainly when there are pathogens such as Fusarium semisectum, however, their development is associated with periods of rain and delays in the harvest, resulting in the deterioration of the seeds, presenting low viability when stored under environmental conditions. This environmental condition is also beneficial for the development and reproduction of Cercospora kikuchii. Higher moisture content favors the occurrence of Aspergillus flavus, the delay in the drying process of the seeds results in great losses of quality due to the effects of the pathogen. These pathogens are minimized with the aid of seed treatment and mainly management during the sowing period, seeking to adjust the development cycles of the cultivars so that they do not coincide with the periods of greater precipitation near the harvest, since the main diseases that affect the seed are associated with high humidity in the harvest. Another important strategy is the desiccation of the crop for harvesting at the phenological stage R7.1 (physiological maturation), as it allows for early harvest and better quality seeds, due to the shorter storage period in the field. 
The vigor analysis is attributed, taking into account the variables that most impact this analysis (Figure 4). Zinc, molybdenum and potassium are the nutrients that are directly linked to the vigor of the seeds. Thus, it was observed that $\mathrm{Zn}$ contents greater than or equal to $46 \mathrm{mg} / \mathrm{g}$ in the seed imply a reduction in vigor from $77 \%$ to $71 \%$. Following the axis of the tree, if the Mo content is greater than or equal from $1 \mathrm{mg} \mathrm{kg}^{-1}$ to $2 \mathrm{mg} \mathrm{kg}^{-1}$, there is a reduction of $71 \%$ to $66 \%$ in vigor, however, less than $1 \mathrm{mg} \mathrm{kg}^{-1}$ increases the vigor from $71 \%$ to $79 \%$, it was noticed, then, the negative influence of high levels of $\mathrm{Zn}$ and Mo in the vigor of the seeds.

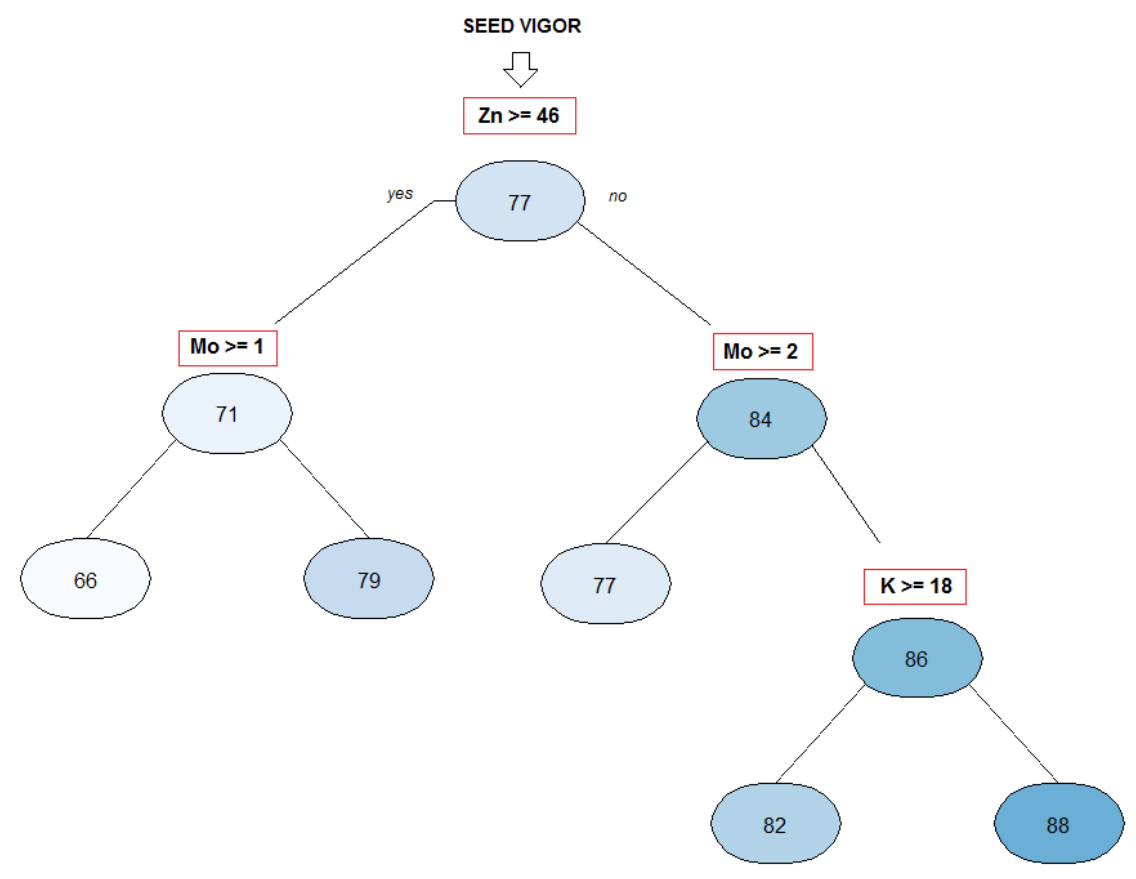

Figure 4. Decision-making tree, where vigor is the dependent variable (AA) representing the trunk of the tree, indicating the beginning of decisions. The independent variables $\mathrm{Zn}, \mathrm{Mo}, \mathrm{K}$ and EA represent the leaves of the tree, these are responsible for the trend of decision making, as they directly influence this action, Campos Borges - Rio Grande do Sul State, 2019.

On the other hand, analyzing the possible decision opposite to the previous one, it can be noted that $\mathrm{Zn}$ contents below $46 \mathrm{mg} \mathrm{kg}^{-1}$ go from a vigor of $77 \%$ to $84 \%$, providing greater seed quality, in the same way, if the Mo is equal to or greater than $2 \mathrm{mg} \mathrm{kg}^{-1}$, there is a decrease of $84 \%$ to $77 \%$ of vigor. Still, less than $2 \mathrm{mg} \mathrm{kg}^{-1}$ of Mo the vigor reaches $86 \%$, being optimized for $88 \%$ or reduced to $82 \%$ if the $\mathrm{K}$ content is less than $18 \mathrm{~g} \mathrm{~kg}^{-1}$ or greater and equal to $18 \mathrm{~g} \mathrm{~kg}$, respectively. 
Thus, high levels of salts, such as $\mathrm{Zn}$ and Mo, in the composition of seeds interfere negatively in vigor, consequently reducing its physiological quality.

To perform similarity and dissimilarity analysis between the genotypes, the dendrogram (Figure 5) was used, which takes into account the presence and effects of the variables. Expressively, the IRC 50 genotype is the most distinct from the others because it has a high incidence of Cercospora kikuchii and a high Fe content, however, it shows lower levels of Mn and Mo. The IRC 25 genotype is distinguished from the others due to its low germination percentage, accelerated aging and tetrazolium. The genotypes IRC 4 and IRC 5 are similar to each other, differing only in relation to Cercospora kikuchii, but differ from the others due to the high levels of $\mathrm{Zn}$ and Na present in the seeds. Note that the IRC 14, IRC 45, IRC 47, IRC 48, IRC 15, IRC 46 genotypes have similarities in the analyzed variables, on the other hand, they show contrast to other genotypes due to low Fe levels and high levels of Mn. The IRC 10 genotype has no similarity with the others, as it exhibits low germination rates, accelerated aging and tetrazolium, and also a high incidence of Cercospora kikuchii and high Mo content. However, the other genotypes have similarities, because they do not exhibit extreme results in most variables.

Through multivariate analysis (Figure 6), it is possible to represent the variables that have affinity with the determined evaluated genotypes. The IRC 37 genotype has a strong affinity with Mo, as does the IRC 24 genotype with Ca and Mg. In addition, the genotypes IRC 34, IRC 14, IRC 30 show affinity with $\mathrm{Mn}, \mathrm{K}, \mathrm{Cu}$, respectively, and the genotypes IRC 40 and IRC 50 with S. Note the affinity of the genotypes with the health variables, showing affinity between the IRC 26 genotype and Aspergillus flavus, as well as the IRC 36 and IRC 15 genotypes show affinity with Cercospora kikuchii. Likewise, the IRC 44 genotype has a strong affinity with the thousand grain mass. 


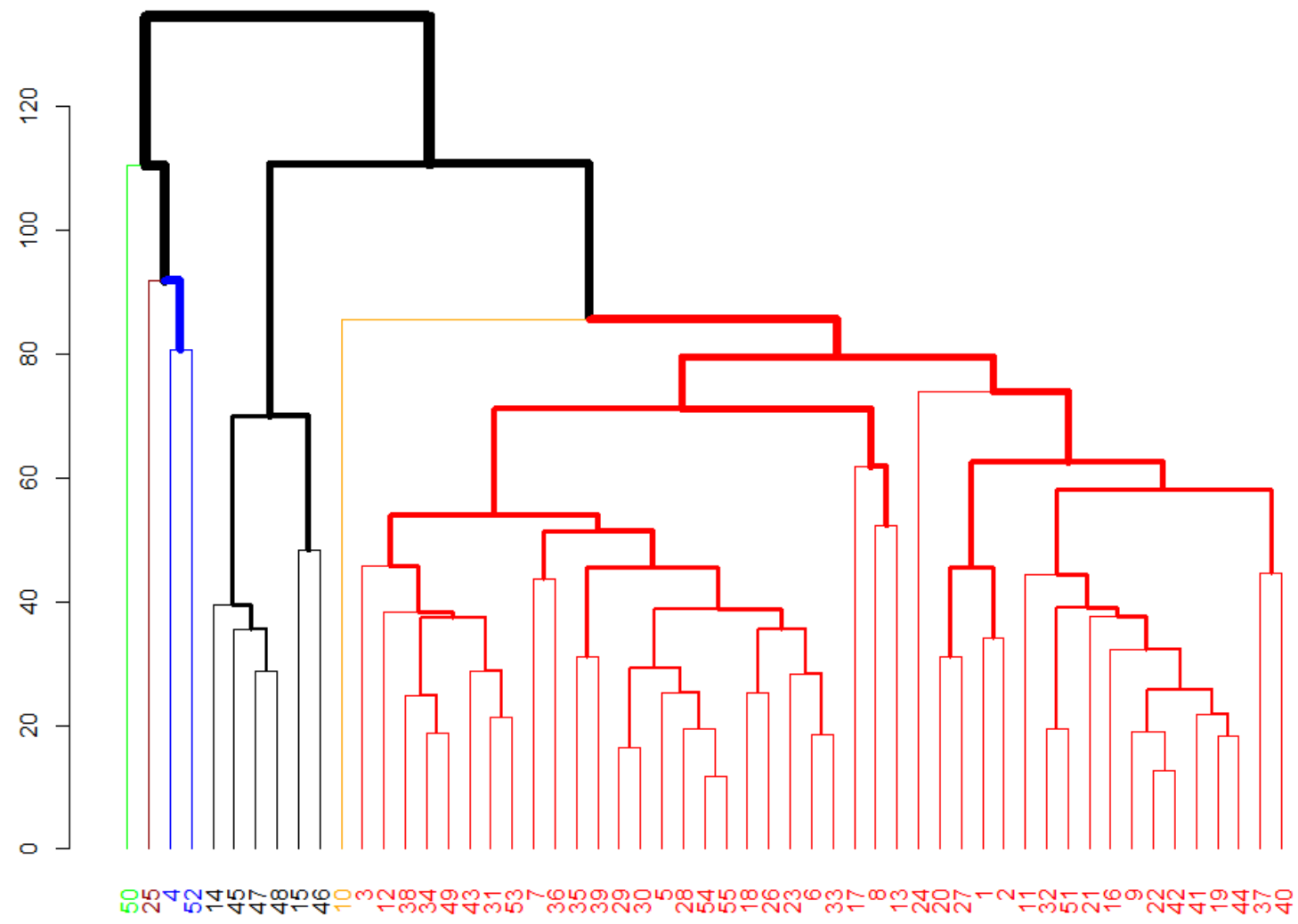

Attributes of soybean seeds

Figure 5. Dendrogram with genetic dissimilarity in 55 soybean F6 genotypes, (IRC 01, IRC 02, IRC 03, IRC 04, IRC 05, IRC 06, IRC 07, IRC 08, IRC 09, IRC 10, IRC 11, IRC 12 , IRC 13, IRC 14, IRC 15, IRC 16, IRC 17, IRC 18, IRC 19, IRC 20, IRC 21, IRC 22, IRC 23, IRC, 24, IRC 25, IRC 26, IRC 27 IRC 28, IRC 29, IRC 30, IRC 31, IRC 32, IRC 33, IRC 34, IRC 35, IRC 36, IRC 37, IRC 38, IRC 39, IRC 40, IRC 41, IRC 42, IRC 43, IRC 44, IRC 45, IRC 46, IRC 47, IRC 48, IRC 49, IRC 50, IRC 51, IRC 52, IRC 53, IRC 54, IRC 55) using the standardized Euclidean distance, obtained by the medium link method (UPGMA), 2018/2019 crop season, Campos Borges - Rio Grande do Sul State, 2019. 


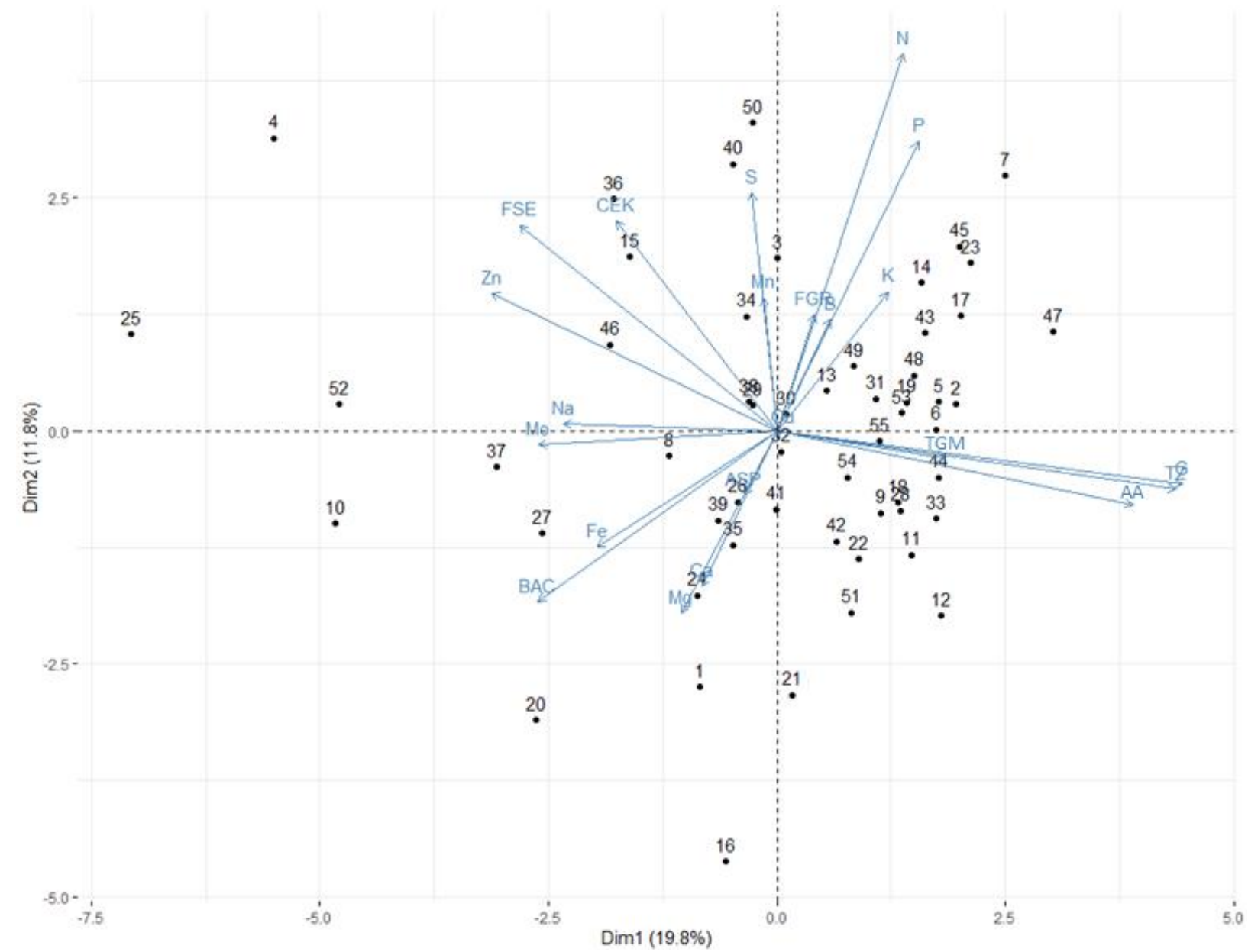

Figure 6. Results of the analysis of the graphic dispersion of the variables Thousand Grains Mass (TGM), Germination percentage (G), Accelerated aging (AA); Tetrazolium (TZ), Aspergillus flavus (ASP), Cercospora kikuchii (CEK), Fusarium graminearum, (FGR), Fusarium semisectum (FSE), Bacteriosis (BAC), Nitrogen (N), Potassium (K), Phosphorus (P), Calcium (Ca), Magnesium (Mg), Sulfur (S), Boron (B), Copper (Cu), Iron (Fe), Manganese (Mn), Zinc (Zn), Sodium (Na), Molybdenum (Mo), in relation to the 55 soybean genotypes (IRC 01, IRC 02, IRC 03, IRC 04, IRC 05, IRC 06, IRC 07, IRC 08, IRC 09, IRC 10, IRC 11, IRC 12, IRC 13, IRC 14 , IRC 15, IRC 16, IRC 17, IRC 18, IRC 19, IRC 20, IRC 21, IRC 22, IRC 23, IRC, 24, IRC 25, IRC 26, IRC 27 IRC 28, IRC 29, IRC 30, IRC 31, IRC 32, IRC 33, IRC 34, IRC 35, IRC 36, IRC 37, IRC 38, IRC 39, IRC 40, IRC 41, IRC 42, IRC 43, IRC 44, IRC 45, IRC 46, IRC 47, IRC 48, IRC 49, IRC 50, IRC 51, IRC 52, IRC 53, IRC 54, IRC 55), 2018/2019 crop season, Campos Borges - Rio Grande do Sul State, 2019. 


\section{CONCLUSION}

The physiological quality of the seeds is negatively affected by the health aspects of Cercospora kikuchii, Aspergillus flavus, Fusarium semisectum and Bacteriosis, in addition, nutritional aspects also act negatively due to the presence of salts, and positive due to the levels of P. Likewise, Zn, Mo and K are correlated as strong indicators of seed vigor levels. The developed genotypes have excellent behavior towards pathogens and seed nutrition, contributing to high quality seed production.

\section{REFERENCES}

ALBANEZE, R; VILLELA, FA; POSSENTI, JC; GUOLLO, K; RIEDO, IC 2018. Danos mecânicos causados pelo uso de graneleiro no transporte, durante a colheita de sementes de soja. Journal of Seed Science. Londrina - Brasil. v. 40, n. 4, p. 422-427. https://doi.org/10.1590/2317-1545v40n4174101.

BRUNINI, MA; DE LIMA, MAB; PEREIRA, M; CERQUEIRA, JB; MENEZES, PTR; FURTADO, IR 2016. Qualidade de grãos de onze cultivares de soja.Nucleus Animalium, Ituverava - Brasil, v. 8, n. 2, p. 8. https://doi.org/10.3738/21751463.2154.

CANTARELLI, LD; SCHUCH, LOB; TAVARES, LC; RUFINO, CA 2015. Variabilidade de plantas de soja originadas de sementes de diferentes níveis de qualidade fisiológica. Acta

Agronómica, Palmira, Colombia, v. 64, n. 3, p. 234-238. Doi: http://dx.doi.org/10.15446/acag.v64n3.45511.

CARVALHO IR; NARDINO, M; PELEGRIN, AJ; HOFFMANN, JF; POLETO, SM; FERRARI, M; SZARESKI, VJ; MEIRA, D; CHAVES, FC; SOUZA, VQ; MAIA, LC 2016. Estimate of genetic parameters in bioactive and micronutrients compounds of maize. African Journal of Agricultural Research, Abuja, Nigeria, v. 11, p. 3123-3133. https://doi.org/10.5897/AJAR2016.11329.

GABARD, G; PRIA, MD; SILVA, HL; HARMS, MG 2020. Alternative products on Asian soybean rust control and their influence on defoliation, productivity and yield components.Summa Phytopathologica, São Paulo, Brasil, v. 46, n. 2, p. 98104.https://doi.org/10.1590/0100-5405/231561

GORDIN, CRB; MARQUES, RF; MASETTO, TE; SOUZA, LCFD 2012. Estresse salino na germinação de sementes e desenvolvimento de plântulas de niger (Guizotia abyssinica (Lf) Cass.) Acta bot. bras, Brasília - Brasil, 26(4): 966-972. https://doi.org/10.1590/S010233062012000400026.

MARIN, RDSF; BAHRY, CA; NARDINO, M; ZIMMER, PD 2015. Efeito da adubação fosfatada na produção de sementes de soja. Revista Ceres, Viçosa, Brasil, v. 62, n. 3, p. 265274.https://doi.org/10.1590/0034-737X201562030006.

MEDEIROS, JGF; NETO, ACA; SILVA, EC; HUANG, MFN; NASCIMENTO, LC 2014. Qualidade sanitária de sementes de Caesalpinia ferrea: incidência de fungos, controle e efeitos na qualidade fisiológica com o uso de extratos vegetais. Floresta, Viçosa, Brasil, v. 45, n. 1, p. 163-174, 2014. http://dx.doi.org/10.5380/rf.v45i1.34074 
OLIVEIRA, NTD; REZENDE, PMD; BRUZI, AT; MELVILLE, CC 2018. Biofortificação com doses de zinco em cultivares de soja tipo-alimentação. Revista de Ciências Agrárias, Lisboa - Portugal. v. 41, n. 3, p. 61-70. http://dx.doi.org/10.19084/RCA17151

PEREIRA, CE; PEREIRA, MC; BRITO JUNIOR, JG; MACHADO, JC 2017. Sementes de soja infectadas por Cercospora kikuchii, sob déficit hídrico. Científica, Jaboticabal - Brasil, v.45, n.3, p.295-299. http://dx.doi.org/10.15361/1984-5529.2017v45n3p295-299.

SALUM, JD; ZUCARELI, C; GAZOLA, E; NAKAGAWA, J 2008. Características químicas e fisiológicas de sementes de feijão em função do teor de fósforo na semente e doses de fósforo no solo. Revista Brasileira de Sementes, Londrina - Brasil. v.30 p. 140-149. https://doi.org/10.1590/S0101-31222008000100018.

SANTOS, DRD; GATIBONI, LC; KAMINSKI, J 2008. Fatores que afetam a disponibilidade do fósforo e o manejo da adubação fosfatada em solos sob sistema plantio direto. Ciência Rural, Santa Maria - Brasil, v. 38, n. 2, p. 576-586. https://doi.org/10.1590/S010384782008000200049.

STRUKER, S; CARVALHO, IR; SZARESKI, VJ; BARBOSA, MH; DE SOUZA, VQ.; CONTE, GG; MARTINS, ABN; CAVALCANTE, JAC; KOCH, F; SCHUCH, LOB; AUMONDE, T Z; VILLELA, FA; PEDÓ, T 2019. Influence of seeds vigor in the attributes of soybean yield. Revista de Ciências Agrárias, Lisboa - Portugal v. 42, n. 3, p. 698-703. https://doi.org/10.19084/rca.16389

SZARESKI, VJ; CARVALHO, IR; DEMARI, GH; KEHL, K; PELISSARI, G; PELEGRIN, AJ; BARBOSA, MHB; ROSA, TC; SANTOS, NL; MARTINS, TS; NARDINO, M; PEDÓ, T, SOUZA, VQ; AUMONDE, TZ 2018a. Path analysis of agronomic traits in soybean cultivars with determinate and indeterminate growing habits. Australian Journal of Crop Science, Sydney - Australia, v. 12, n. 4, p. 531. https://doi.org/10.21475/ajcs.18.12.04.pne608.

SZARESKI, VJ; CARVALHO, IR; DEMARI, GH; ROSA, TCD; SOUZA, VQD; VILLELA, F A; PEDÓ, P; AUMONDE, TZ 2018b. Multivariate index of soybean seed vigor: a new biometric approach applied to the effects of genotypes and environments. Journal of Seed Science, Londrina - Brasil, v. 40, n. 4, p. 396-406. https://doi.org/10.1590/2317$1545 v 40 n 4198333$

VALÁRIO, BP; CAVARIANI, C; FRANÇA-NETO, JDB; VIEIRA, ESN; BRAVO, JP; SILVA, EAAD 2014. Uso do alelo" EP"(Peroxidase) na caracterização varietal de soja. Journal of Seed Science, Londrina - Brasil, v. 36, n. 4, p. 465-470. https://doi.org/10.1590/2317$1545 v 36 n 4996$.

ZAMBIAZZI, EV; BRUZI, AT; ZUFFO, AM; SOARES, IO; MENDES, AES; TERESANI, ALR; MOREIRA, SG 2017. Desempenho agronómico e qualidade sanitária de sementes de soja em resposta à adubação potássica. Revista de Ciências Agrárias, Recife - Brasil, v. 40, n. 3, p. 543-553. http://dx.doi.org/10.19084/RCA16055 